\title{
Correction to: The long pentraxin PTX3: a novel serum marker to improve the prediction of osteoporosis and osteoarthritis bonerelated phenotypes
}

Virginia Veronica Visconti ${ }^{1,2}$, Chiara Greggi ${ }^{1,2}$, Simona Fittipaldi ${ }^{1}$, Donato Casamassima ${ }^{2}$, Mariagrazia Tallarico ${ }^{2}$, Francesco Romano ${ }^{2}$, Annalisa Botta ${ }^{1 *+}$ and Umberto Tarantino ${ }^{2,3+}$

Correction to: J Orthop Surg Res 16, 288 (2021)

https://doi.org/10.1186/s13018-021-02440-3

Following the publication of the original article [1], the authors noticed that the given name of one of the authors has been captured incorrectly. Maria Grazia Tallarico should be Mariagrazia Tallarico. The correct name is shown in the author group section above.

The original article has been corrected.

\begin{abstract}
Author details
${ }^{1}$ Department of Biomedicine and Prevention, Medical Genetics Section, University of Rome "Tor Vergata", Via Montpellier 1, 00133 Rome, Italy. 2Department of Orthopaedics and Traumatology, "Policlinico Tor Vergata" Foundation, Viale Oxford 81, 00133 Rome, Italy. ${ }^{3}$ Department of Clinical Sciences and Translational Medicine, University of Rome "Tor Vergata, Via Montpellier 1, 00133 Rome, Italy.
\end{abstract}

Published online: 21 May 2021

\section{Reference}

1. Visconti W, Greggi C, Fittipaldi S, Casamassima D, Tallarico MG, Romano F, et al. The long pentraxin PTX3: a novel serum marker to improve the prediction of osteoporosis and osteoarthritis bone-related phenotypes. J Orthop Surg Res. 2021;16(1):288. https://doi.org/10.1186/s13018-021-0244 $0-3$.

The original article can be found online at https://doi.org/10.1186/s13018021-02440-3.

* Correspondence: botta@med.uniroma2.it

${ }^{\dagger}$ Annalisa Botta and Umberto Tarantino contributed equally to this work. ${ }^{1}$ Department of Biomedicine and Prevention, Medical Genetics Section, University of Rome "Tor Vergata", Via Montpellier 1, 00133 Rome, Italy

Full list of author information is available at the end of the article

C C The Author(s). 2021 Open Access This article is licensed under a Creative Commons Attribution 4.0 International License, which permits use, sharing, adaptation, distribution and reproduction in any medium or format, as long as you give appropriate credit to the original author(s) and the source, provide a link to the Creative Commons licence, and indicate if changes were made. The images or other third party material in this article are included in the article's Creative Commons licence, unless indicated otherwise in a credit line to the material. If material is not included in the article's Creative Commons licence and your intended use is not permitted by statutory regulation or exceeds the permitted use, you will need to obtain permission directly from the copyright holder. To view a copy of this licence, visit http://creativecommons.org/licenses/by/4.0/ The Creative Commons Public Domain Dedication waiver (http://creativecommons.org/publicdomain/zero/1.0/) applies to the data made available in this article, unless otherwise stated in a credit line to the data. 